\section{Conservation on the move}

Mobile telephone services have developed in both scope and sophistication at an extraordinary rate. Unlike many other technical innovations, which are often restricted to the world's wealthy minority, mobile phones are also becoming integrated into the lives of people in developing countries. There is a challenge to find innovative ways to ensure that this new opportunity in communications is used to generate benefits for the global community and the earth's environment. The technology and services available through the phones have to meet the needs of poor communities, and bridges must be built to span the 'digital divide'.

One route through which Fauna \& Flora International (FFI) pursues its mission is by working together with multinational companies such as Vodafone to redress the impoverishment of natural and human communities. An essential requisite to accomplish environmental recovery and sustainability is effective communications. To this end FFI has signed an agreement with the Vodafone Group Foundation (Vodafone's charitable trust) to investigate the opportunities to utilize the very latest tools and thinking in telecommunications to aid those working to reverse the decline of the earth's natural systems, empowering the most disadvantaged societies, and reinvesting in local communities.

Working with Vodafone, FFI is seeking to raise awareness of conservation with people who are actively interested in using cutting edge technologies. The idea is for mobile phone users to be able to connect to conservation projects around the world. They could potentially have access to conservation project information, pictures and news, and become more actively involved in conservation by being able to respond directly to specific projects. There will also be opportunities for phone users to be able to donate money via their mobile phone. Vodafone plc is the largest telecommunications operator, with $10 \%$ of the market worldwide - over 100 million mobile users and growing - and so there is enormous potential in this project to connect with large numbers of people about conservation.

In developing countries cash flow problems in small enterprise start-ups are a major issue. The lack of access to banking facilities means that local entrepreneurs in rural areas are often vulnerable to exploitation by unscrupulous credit sources for the sake of very small financial credit.
Poverty alleviation and sustainable management of natural resources are inextricably linked, and so in response to the edicts of the recent World Summit on Sustainable Development, this project will also consider whether mobile phones can be a delivery mechanism for financial services. This is a realistic opportunity because, firstly, mobile phone uptake is growing rapidly in developing countries, linking even remote communities to the outside world and, secondly, handsets and phone bills can be used to make payments and credit transfers for an increasing range of goods and services. This exciting vision would be to link reputable financial services and the donation of funds from the more affluent people with conservation interests to local communities who need small levels of credit for biodiversity-based community livelihood projects and small business initiatives. The proliferation of mobile phone use may be able to answer some of the needs of poor communities.

\section{Bill Parker}

Fauna \& Flora International, Great Eastern House

Tenison Road, Cambridge, CB1 2TT, UK

E-mail: bill.parker@fauna-flora.org

\section{New species of plants discovered in Sapo National Park, Liberia}

In late 2002 a joint expedition of the University of Liberia (Prof. F. Blyden and staff \& students of the University) and Wageningen University, The Netherlands (Dr. C. C. H. Jongkind), conducted the first ever botanical expedition to Sapo National Park in south-east Liberia. It was supported by Fauna \& Flora International in the context of the project A Re-assessment of Forest Cover, Updating of the Protected Forest System, and Improvement of Environmental Information for Liberia, funded by the European Union and the Critical Ecosystems Partnership Fund.

In less than two weeks in the Jalay's Town area of Sapo National Park the team of botanists and students found 350 different species of vascular plants. Of these at least $22 \%$ are endemic (a percentage that is high for lowland forest in tropical Africa), six species are new to science, and some of the specimens not yet identified may also be new. The Sinoe River and several of its tributaries pass through the area surveyed, resulting in a relatively high number of swamp and riverside forest plants amongst the species collected. The part of the 
Park surveyed is particularly rich in herbaceous and small shrubby forest plants, found growing in the shade on the forest floor and also on the boles and high up on the branches of trees. On the way back to Monrovia the team spent 2 days in the forests of Inland Logging Company's concession between the Cestos and Senkwehn Rivers, $10-20 \mathrm{~km}$ from the coast. Here 90 plant species were collected of which $30 \%$ are endemic to the Upper Guinean forest ecosystem.

Amongst the species collected were the following noteworthy plant species: Cercestis taiensis (Araceae), described as recently as 1995, is a species previously believed to be endemic to south-west Côte d'Ivoire; it was found to be a common herbaceous plant on the forest floor in both Sapo National Park and in the Cestos-Senkwehn forests. Sciaphila africana (Triuridaceae) is a rare parasitic herb known only from a few locations in the forests of West Africa and now also from the Park. Cnestis bomiensis (Connaraceae) is a large liana, which until last year was only known from the west and north of Liberia, from where it was first described in 1989. Bertiera spec. nov. (Rubiaceae) is a small woody liana awaiting formal naming; it was recently discovered in old herbarium collections from the Nimba Mountains, but has now been found in both the Park and the Cestos-Senkwehn forests. Salacighia linderi (Celastraceae) was previously known only from Sierra Leone and elsewhere in Liberia, and its occurrence in the Park is the first time it has been found in eastern Liberia's lowland forests. Keetia bridsoniae (Rubiaceae) is a large liana that was only described at the end of 2002. Cephaelis micheliae (Rubiaceae) a shrub growing in the forest shade that was previously known only from one location in central Liberia, but now also from the Cestos-Senkwehn forests.

This news follows on from news of developments in conservation in Liberia highlighted in the April 2002 issue of $\operatorname{Oryx}(36(2), 112-113)$ and of the exceptional conservation potential of Sapo National Park described in the January 2002 issue (36(1), 11-12).

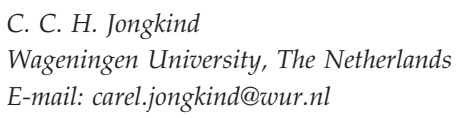

\section{New information on the lowland coastal forests of eastern Africa}

Much of the data in a recent compilation of information on the coastal lowland forests of eastern Africa (N. D. Burgess. \& G. P. Clarke, eds, 2000, The Coastal Forests of Eastern Africa. IUCN Forest Programme, Gland, Switzerland and Cambridge, UK), a region that is amongst the most important areas for global biodiversity conservation, were gathered in the early 1990s. Over the past few years a programme coordinated from the WWF office in Nairobi (http://www.worldwildlife.org/ecoregions) has brought together representatives from the three countries that contain large areas of coastal lowland forest (Kenya, Tanzania and Mozambique), and developed a common vision on the way forward for conservation in this region. The programme also formed national task forces that have now met, and engaged a coastal forest ecoregion coordinator. This WWF-facilitated work, complemented by recent research funded through the Critical Ecoregion Partnership Fund (http:/ /www.cepf.net) has provided a particularly interesting update on the status and biodiversity importance of these forests (WWFEARPO, 2002, Coastal Forests of Eastern Africa: Action Plan. WWF EARPO, Nairobi, Kenya).

The coastal strip of eastern Africa contains a mosaic of vegetation types. Much of the area supports bushland/ thicket habitats and coastal variants of savannah woodland habitats, but there are also smaller areas of wetland, and patches of lowland forest. The total area of land covered by this mosaic of habitats is c. $260,000 \mathrm{~km}^{2}$. Data gathered on the lowland forests over the past year have revealed the existence of 154 forest patches, covering c. $3,107 \mathrm{~km}^{2}$, that were not included in the earlier compilation, with the largest increase in recorded forest area being in Mozambique. These increases are due to increased survey work rather than to any forest regeneration between 1992 and 2002. On the contrary, site visits in Kenya and Tanzania have indicated that forest area is declining, with the most dramatic losses occurring close to major cities. For example, outside Dar es Salaam there has been extensive forest loss in the Pugu/Kazimzumbwi, Ruvu South and Masanganya Forests Reserves. The situation is, however, different in northern Mozambique, where large and apparently unthreatened expanses of forest habitat, grading into bushland and woodland, remain (N. D. Burgess et al., 2003, The Arc Journal, 15, 9-12).

Most of the larger coastal forest fragments in Kenya and Tanzania are found within government Forest Reserves, although there are numerous small patches in 'sacred groves' and some areas on private lands such as sisal estates. The important coastal forest of Zaraninge in Tanzania is in the process of being included within an expanded Sadaani Game Reserve, which will become a new National Park. In Mozambique there are large areas of forest remaining on village and 'empty' lands, several $100 \mathrm{~km}^{2}$ of which have recently been included within the new Quirimbas National Park, declared in June 2002.

The eastern African coastal forest mosaic contains c. 1,750 endemic species, and within this the lowland forest habitat is the most biologically valuable, with 554 endemic plant species and 52 endemic vertebrates. The surrounding non-forested vegetation of the coastal 
strip is also important, containing at least 812 endemic plant species and 47 endemic vertebrates (http:// www.worldwildlife.org/ecoregions). Although there are more endemic species in the non-forest vegetation types, these habitats cover at least $255,000 \mathrm{~km}^{2}$ (0.3 endemic species per $100 \mathrm{~km}^{2}$ ), whereas the coastal forests cover a total of $6,259 \mathrm{~km}^{2}$ (9.6 endemic species per $100 \mathrm{~km}^{2}$ ). Clearly the forest patches have the highest biodiversity importance per unit area. Many of the endemic species have tiny geographical ranges, with 'single-site' endemism being commonplace. As a consequence of these small ranges and the restricted and declining area of coastal forests, a large number of these species are threatened with extinction (http://www.biodiversityscience.org).

New species of animals and plants continue to be discovered in the coastal forests. Over the past 10 years four new species of mammal, two new species of reptile and a new species of amphibian have been named, almost all found within forest habitats. Of particular interest are the new species of mammals. One of these involves the upgrading of the Zanzibar red colobus to a full species, Procolobus kirkii, and the other three are galagos, or bushbabies (Grubb et al., International Journal of Primatology, in press). Clearly there is much still to learn about these forests. In particular, the forests of northern Mozambique remain relatively unknown biologically and may well support new species in many taxonomic groups.

\section{Neil Burgess}

WWF-US Conservation Science Programme

1250 24th Street, NW Washington, DC, USA

E-mail: neil.burgess@wwfus.org

Nike Doggart, Kathryn Doody \& Andrew Perkin

Tanzania Forest Conservation Group

P.O. Box 23410, Dar es Salaam, Tanzania

Gezahegn Negussie

WWF Eastern Africa Regional Programme Office

P.O. Box 62440, 00200 Nairobi, Kenya

Peter Sumbi

WWF Tanzania Programme Office

P.O. Box 63117, Dar es Salaam, Tanzania

\section{Conservation of thicket biodiversity in South Africa}

The goal of the STEP (Subtropical Thicket Ecosystem Planning) project, managed by the Terrestrial Ecology Research Unit at the University of Port Elizabeth, South Africa, and co-funded by the Global Environment Facility through the World Bank, is "To promote the conservation of globally significant biodiversity in the Thicket Biome". The Thicket Biome is one of South
Africa's seven biomes and one that has been identified as requiring urgent conservation attention. It is an internationally recognized centre of plant diversity and endemism, especially for succulents and bulbs ( $21 \%$ of its plant species are endemic). The biome is also a centre of high vertebrate diversity and biomass, and it provides prime habitat for a number of charismatic and ecologically and economically important species, such as African elephant and black rhinoceros.

Apart from its globally important biodiversity, the Thicket Biome also provides the resource base for a wide range of activities that provide employment for thousands of people in a part of South Africa where poverty is rife in many rural areas. For example, South Africa provides c. $60 \%$ of the world's mohair, and more than $80 \%$ of the national mohair production comes from the Thicket Biome. This biome also provides an important resource base for the fast growing tourism and hunting industries, and large numbers of commercial stock farms are converting to these two wildlife-based industries. Thicket vegetation is also an important resource for the horticultural and medicinal plant industries.

The Thicket Biome is, however, under serious threat from a range of human-related activities, mainly overgrazing by domestic stock, bush clearing for crop agriculture and urban and resort development, and invasion by alien vegetation. The project has revealed alarming levels of degradation and transformation of the thicket. Over $42 \%$ of the area covered by dense thicket has been either "severely degraded" (has markedly reduced woody biomass and loss of functionality) or "transformed" (by total removal of thicket). Once thicket has reached these two states, restoration to a functional ecosystem is not feasible.

Apart from creating an awareness of the value and plight of the Thicket Biome, providing a detailed spatial analysis of the various thicket types, assessing the extent of their transformation and developing a better understanding of the threats, the STEP project will locate and design conservation areas to achieve explicit biodiversity representation goals, and suggest and prioritize explicit conservation actions. The three main project outcomes will be: (1) A strategic, systematic and flexible conservation plan that will identify an implementation priority schedule based on the conservation value ("irreplaceability"), and vulnerability to threatening processes, of individual planning units; (2) an implementation strategy and action plan that will identify appropriate incentives for participation of landowners in the establishment of conservation sites in priority areas, the suitability of alternative, biodiversity-friendly, forms of land use in priority areas, appropriate (informal) institutions that can facilitate effective implementation, ways in which existing (formal) institutions and legal frameworks can 
be re-aligned to support the STEP planning outcomes, and the socio-economic implications of the effective implementation of the STEP planning outcomes; (3) capacity building (training) for land-use planners, especially at local government level, in the use of the spatial planning outcomes.

Further information on the project, which commenced in July 2000 and is due for completion in June 2004, can be found at http://www.zoo.upe.ac.za/step

Dr André Boshoff

Terrestrial Ecology Research Unit, University of Port Elizabeth

P.O. Box 1600, Port Elizabeth, 6000, South Africa

E-mail:zlaafb@zoo.upe.ac.za

\section{Court saves unique wildlife habitat in India}

In October 2002 Wildlife First, a pro-active conservation group, won a battle against Kudremukh Iron Ore Mining Company Limited (KIOCL), to save the unique Kudremukh National Park $\left(563 \mathrm{~km}^{2}\right)$ in southern India. The Park lies in the Western Ghats, identified as one of the world's 25 biodiversity 'hotspots', and also forms a part of the Level-I Tiger Conservation Unit. Habitats in the Park include tropical evergreen forests and high altitude grasslands, and the Park is the largest protected area of wet evergreen 'shola' forest (short stature valley forests) in the Western Ghats. Several globally significant, rare and threatened animal species occur in the Park, including the tiger Panthera tigris, leopard Panthera pardus, Indian wild dog Cuon alpinus, lion-tailed macaque Macaca silenus, great hornbill Buceros bicornis, king cobra Ohphiophagus hannah, Malabar civet Viverra megaspila, and possibly the Nilgiri marten Martes gwatkinsi.

The area was declared a National Park in 1987 after Ullas Karanth of the Wildlife Conservation Society identified a significant population of lion-tailed macaque in the area. The Park is contiguous with other forest areas that together form nearly $1,000 \mathrm{~km}^{2}$ of important wildlife habitat. The area receives an annual rainfall of c. 7,000 $\mathrm{mm}$ and performs critical hydrological and other ecosystem functions that are vital for the social and economic life of the region. Three major rivers originate from the area, irrigating millions of hectares of farmland in the states of Karnataka and Andhra Pradesh in southern India.

KIOCL is an open cast mining company. It has operated in a $37 \mathrm{~km}^{2}$ enclosure inside the Park for the past three decades and has also established roads, bridges and high-tension electric lines through the Park that have fragmented wildlife habitats. The mining has brought large human settlements into the reserve for the workforce and ancillary services. The mining operation has polluted a major river, the Bhadra, affecting the livelihood of millions of farmers downstream. A recent hydrological study, conducted with support from the Wildlife Conservation Society, has shown that the sediment load of the Bhadra River is 20 times higher downstream than upstream from the mining area.

A legal suit was filed in the Supreme Court of India by K.M. Chinnappa, president of Wildlife First, in association with Legal Action for Wildlife and Environment (LAW-E), a New Delhi-based NGO. Wildlife First and its other conservation partners Kudremukh Wildlife Foundation, Nature Conservation Guild, Greenwatchers and Arohana launched a major news and outreach campaign to influence the Government, decision makers and opinion builders in order to prevent the extension of the mining lease that expired on 24 July 1999. The campaign garnered support from key political leaders, media personnel and religious institutions to build public opinion against continuation of the mining operations. In a ground-breaking judgement, and for the first time in the history of the country, the ecologically devastating mine was required by the Supreme Court of India to end its operations by the end of 2005. At the time of writing, Wildlife First has proposed that the mined area, which was illegally removed from the limits of the National Park, be included in the Park.

Sanjay Gubbi,

Centre for Wildlife Studies, 823, 13th Cross, 7th Block West Jayanagar, Bangalore - 560 082, India

E-mail: gubbi@wcsindia.org

\section{World Parks Congress, September 2003}

Every 10 years the World Commission on Protected Areas (WCPA) convenes a World Parks Congress to review the state of the global protected areas estate and to address the needs for the coming decade. In September of this year the 5th Congress will be held in Durban, South Africa (see http://www.iucn.org/themes/wcpa for details). The event will see significant partnerships between government agencies managing parks, the intergovernmental sector, especially the UNEP-World Conservation Monitoring Centre, and a spectrum of the world's major NGOs, who have been assisting in organizing sessions and compiling data to be presented at the Congress.

Four major sessions will address the current issues for the worlds protected areas, ranging from how protected areas can bring benefits to people, community-approaches to protected areas, how to work at large scales, and how to manage change. Two additional sessions will look at the development of global partnerships for protected areas, and there is a special session on protected areas 
in Africa. Seven workshop streams will also tackle issues of importance to protected areas. One of the streams "building a comprehensive protected area system" aims to assess gaps in the protected area network, and propose where they should be filled, outline the needs for reserves in the marine and freshwater environments, and assess how much a global network of protected areas would cost. The efforts of many agencies, governments and individuals will be reflected here and will set the scene for action connected to parks and the emerging field of community-based and private conservation areas.

The congress will release the updated protected areas database for the world, which will for the first time be made available via the World Wide Web for all interested users. The update of this database has been undertaken by UNEP-WCMC on behalf of the WCPA, and has involved the input of a consortium of NGOs, in particular BirdLife International, Conservation International, Flora \& Fauna International, IUCN, The Nature Conservancy, Wildlife Conservation Society, World Resources Institute and WWF.

\section{Neil Burgess}

WWF-US Conservation Science Programme

1250 24th Street, NW Washington, DC, USA

E-mail: neil.burgess@wwf-us.org

\section{Fourth Student Conference on Conservation Science}

The July issues of Oryx for 2001 and 2002 reported on the continuing success of the second and third Student Conference on Conservation Science, and this year's issue is no exception. The fourth Conference was held in the Department of Zoology, University of Cambridge, UK, during 26-28 March 2003. The number of attendees at this increasingly popular conference rose yet again, with over 240 people, including 138 postgraduate students from 43 countries. Students from Austria, Bolivia, Cameroon, Côte d'Ivoire, Ecuador, Gabon, Madagascar, Mauritius, South Korea, Sudan, Sweden and Venezuela attended for the first time. The conference included 35 talks and 36 posters by research students, and four plenary lectures, given by Bob Pressey (New South Wales Parks and Wildlife Service), Achim Steiner (Director-General, IUCN), Elizabeth Bennett (Wildlife Conservation Society) and Andrew Dobson (Princeton University). A total of 68 staff from 26 conservation agencies, institutes and NGOs attended the Conference and participated in discussions with student delegates. The Conference also included a series of 'how to' workshops on some of the practical skills important to graduate students. The next conference in the series will be held in the Department of Zoology in Cambridge, UK, on 24-26 March 2004.

\section{New and improved internet resources}

ReefBase (http:/ / www.reefbase.org), a comprehensive portal for information on coral reefs, is presented by the WorldFish Center based in Malaysia. Intended for use by reef managers, scientists and the general public, ReefBase aims to "facilitate better understanding of the interdependence between humans and coral reefs, in order to benefit management and conservation efforts of these important resources." ReefBase provides information on coastal and marine resources, coral reef threats, resource management practices, maps and photos, references, and more, searchable by country or territory.

Eco-Index (http://www.eco-index.org), a project of the Rainforest Alliance, is "a searchable almanac of current and past conservation projects in Mesoamerica, with project descriptions, goals, achievements, lessons learned, and more." The information presented covers a range of biodiversity conservation issues. Users can add their own project descriptions to the Eco-Index database. Materials are available in English or Spanish.

Flora of the Hawaiian Islands (http://rathbun.si.edu/botany/ pacificislandbiodiversity/hawaiianflora/index.ht.) is part of a long-term project to "eventually provide the internet community with the most complete reference on the flora of oceanic islands of the Pacific." Presently, available databases provide plant checklists and specimen type data. The site also contains a searchable image gallery and an electronic supplement to the Manual of the Flowering Plants of Hawai'i, the volume that serves as the basis for this site.

\section{Errata}

The item Antiguan racer translocation in the Conservation News section of the January 2003 issue of $\operatorname{Oryx}(37(1), 13)$ contained the following errata: The first translocation of Antiguan racers took place in 1999 (not 2001), seven females and three males were selected for the 2002 translocation (not five males and five females), and four (rather than 10), were fitted with radio transmitters.

\section{Obituary: Dr Ulysses Samuel Seal, June 1929-March 2003}

In March 2003 Ulie Seal, one of the fathers of modern ex situ conservation, passed away after a long battle with cancer. His long career was characterized by an unstoppable energy that drove both people and science towards a better understanding of conservation. Ulie 
reveled in those exciting and unpredictable border zones between scientific research and practical management, conservation and communication techniques, computer modelling and threatened species reproduction, and ultimately the links between wild and captive populations.

Ulie's training started with degrees in Psychology from Emory University $(1949,1950)$ and a PhD in Biochemistry in 1957 with a post-doctoral placement at the University of Minnesota (1957-59). Ulie spent the better part of his career as a research scientist at the Veteran's Administration Medical Center in Minneapolis, but his interests spilled over to the physiology of wild animals and working with zoo veterinarians. Following the invitation of Sir Peter Scott, Ulie served as chairman of the Conservation Breeding Specialist Group (CBSG) of the IUCN Species Survival Commission from 1979. Ulie authored more than 260 peer reviewed journal articles and 70 book chapters and reviews, and whilst finding time to write these he became intensively involved with threatened species conservation, founding the International Species Information System, a global database that provides computerized animal management for more than 500 cooperating zoological institutions worldwide in 72 countries. Ulie received many honors including the AAZPA Marlin Perkins Award (1991), the Chicago Zoological Society's Presidents Award (1992), the Zoological Society of Antwerp's Gold Medal (1993), Emory University's Emory Medal (1993), the U.S. Fish and Wildlife Service Great Lakes-Big Rivers Region Silver Eagle Award (1994) the first Heini Hediger award of the IUDZG (1996), the SSC's Peter Scott Award for Conservation Merit (2002), the San Diego Zoo's Conservation Medal (2002), and the North of England Zoological Society's Gold Medal (2002). In addition, two awards have been created in Ulie's honor: CBSG's Ulysses S. Seal Award for Innovation in Conservation (2002), and SEAZA's Ulie Seal Award (2003).

Two things dominated Ulie's life: he showed extraordinary commitment to his family and to CBSG. From 1982-84 Ulie developed the first model for a Species Survival Plan following the International Tiger Symposium in Leipzig. Under Ulie's leadership CBSG developed a series of working conservation tools that are now widely used: the Conservation Assessment and Management Plan (CAMP) workshop to assess conservation needs and priorities, and the Population and Habitat Viability Assessment, a tool for assessing the conservation needs of a particular species. Similarly CBSG played a pivotal role in supporting Bob Lacy's development of a computer-simulation modelling tool later to become VORTEX. The first CAMP workshop, for primates, was held in 1991. Other innovations included the production in 1986 of the first Global Captive Action Plan for Parrots. The IUCN Policy Statement on Captive Breeding was drafted at the 1986 CBSG Annual Meeting, and revised by CBSG in 2002 after a long, and sometimes exasperating, process of consultation with a wide variety of agencies; "everybody except the prions", to quote Ulie. While CBSG's core activities focused on animals, Ulie was keen to explore other areas and actively fostered work on plant conservation and recognized the imperative of understanding the role of human demography in conservation.

Ulie's traveling for CBSG was extraordinary. Often accompanied by his wife Marialice, he conducted more than 200 CBSG workshops in over 60 countries. This exposed Ulie to a huge variety of problems and experience and in turn, exposed workshop participants to the dynamics of Ulie and the CBSG staff. As CBSG grew, the zoo focus expanded to encompass wildlife managers, non-governmental organizations, governments, and the private sector. Ulie was keen to not only test his team against new boundaries but also to test new techniques; he never lost his intellectual curiosity and a desire to improve established processes.

To say that Ulie was a natural diplomat and promoted understanding and consensus at all times would not be entirely accurate. His desire to question, test and review complex situations made him challenge both the assumed and the expected. I remember one occasion when, facilitating a workshop, I was taken aside by Ulie and told that the there was too much agreement and I was to generate some positive friction. On the other hand he had the extraordinary ability to work with highly disparate groups to discover consensus and excavate important data previously unavailable to conservationists.

Ulie leaves an extraordinary legacy that can be measured in terms of his contribution to improved conservation management skills. CBSG exists as an international network with active regional chapters in Asia, Central America, South Africa and Europe. He created and led one of the most active and productive Species Survival Commission specialist groups. His many friends and colleagues remember an extraordinary individual, who demonstrated a complete commitment to conservation and who was a joy to work with.

Mike Maunder

Director of Horticulture, Fairchild Tropical Garden

10901 Old Cutler Road, Coral Gables

Miami, Florida 33156-4296, USA

E-mail:mmaunder@fairchildgarden.org 